Cahiers $d u$ MONDE RUSSE

\section{Cahiers du monde russe}

Russie - Empire russe - Union soviétique et États indépendants

42/2-4 | 2001

La police politique en Union soviétique, 1918-1953

\title{
The MECHANISMS of the informational activity of the GPU-NKVD
}

The surveillance file of Mykhailo Hrushevsky

Iurii I. SHAPOVAL

\section{CpenEdition}

Journals

Édition électronique

URL : https://journals.openedition.org/monderusse/8450

DOI : $10.4000 /$ monderusse. 8450

ISSN : $1777-5388$

Éditeur

Éditions de l'EHESS

Édition imprimée

Date de publication : 1 avril 2001

Pagination : 207-230

ISBN : 2-7132-1398-3

ISSN : $1252-6576$

Référence électronique

Iurii I. SHAPOVAL, "The MECHANISMS of the informational activity of the GPU-NKVD ", Cahiers du monde russe [En ligne], 42/2-4 | 2001, mis en ligne le 01 janvier 2007, consulté le 03 septembre 2022 URL : http://journals.openedition.org/monderusse/8450; DOI : https://doi.org/10.4000/monderusse. 8450 
chercher : repérer : avancer

Cet article est disponible en ligne à l'adresse :

http://www.cairn.info/article.php?ID REVUE=CMR\&ID NUMPUBLIE=CMR 422\&ID ARTICLE=CMR 4220207

The MECHANISMS of the informational activity of the GPU-NKVD. The surveillance file of Mykhailo Hrushevsky

par lurii I. SHAPOVAL

Editions de I'EHESS | Cahiers du monde russe

2001/2-3-4 - Vol 42

ISSN 1252-6576 | ISBN 2713213983 | pages 207 à 230

Pour citer cet article :

-SHAPOVAL I., The MECHANISMS of the informational activity of the GPU-NKVD. The surveillance file of Mykhailo Hrushevsky, Cahiers du monde russe 2001/ 2-3-4, Vol 42, p. 207-230.

Distribution électronique Cairn pour les Editions de l'EHESS.

(C) Editions de l'EHESS. Tous droits réservés pour tous pays.

La reproduction ou représentation de cet article, notamment par photocopie, n'est autorisée que dans les limites des conditions générales d'utilisation du site ou, le cas échéant, des conditions générales de la licence souscrite par votre établissement. Toute autre reproduction ou représentation, en tout ou partie, sous quelque forme et de quelque manière que ce soit, est interdite sauf accord préalable et écrit de l'éditeur, en dehors des cas prévus par la législation en vigueur en France. Il est précisé que son stockage dans une base de données est également interdit. 


\title{
THE MECHANISMS \\ OF THE INFORMATIONAL ACTIVITY OF THE GPU-NKVD
}

\author{
The surveillance file of Mykhailo Hrushevsky
}

To begin, I will focus briefly on the meaning of the word "dossier" (deloformuliar). As is known, there were two basic categories of secret informers in the Soviet political police: the informer (osvedomitel'), who provided so-called primary information, and the agent (agent), who took part in the operative surveillance of an individual. The keeping of dossiers began with informers. These cases would be opened when information about concrete individuals was considered sufficiently important. Cases were initiated by various operative divisions after preliminary verification of the primary information.

In the case of Mykhailo Hrushevsky, dossier no. 1023 was opened on March 24, 1924, by a resolution of $\mathrm{H}$. Eimontov, the official in charge of the 1st group of the Counter-Intelligence Department of the GPU department of Kyiv guberniia. Like others, this division was engaged in the study of all categories of the population considered important within society at that time, including the scientific intelligentsia.

The main pretext for launching the case was the fact that Hrushevsky was not simply a distinguished Ukrainian scholar, but at one time had also been very engaged in political activity. His "crime" lay in the fact that he had headed the Tsentral'na Rada (Central Council) that resisted the Bolsheviks in 1917-1918. It was this very circumstance that became the basis not only for opening a dossier, but also for gathering further information about him. For this reason the case was launched "according to the coloration (okraska) of Ukrainian counter-revolution."

It is characteristic that the first decision on the opening of a dossier was a kind of experiment. On February 5, 1925, another dossier was opened in accordance with a 
decision passed by Borin, the official in charge of the Counter-Intelligence Department of the GPU department of Kyiv guberniia. This resolution, in contrast to H. Eimontov's, was more categorical. Here the scholar was already marked as a "Ukrainian chauvinist," and the accumulated materials gave the green light to suspect him of "anti-Soviet activity." At the same time, according to tradition, the Chekists gave the academician the pseudonym "Staryk" (Old Man).

Mykhailo Hrushevsky returned from involuntary emigration in Vienna on March 8, 1924. In his view, his return was an act of compromise. He had fulfilled the Bolsheviks' demand that he abandon his tireless political activity in the Ukrainian Party of Socialist Revolutionaries (UPSR). He had publicly declared his loyalty to the Communist regime that was then carrying out the policy of "Ukrainization" and had accepted a proposal to eventually occupy the post of president of the All-Ukrainian Academy of Sciences (Vse-Ukrainska Akademiia Nauk - VUAN).

However, Hrushevsky, who did not trust the new rulers, had managed to obtain two written documents that were akin to "decrees of protection." The first was a letter from the All-Ukrainian Central Executive Committee (Vseukrainskyi Tsentral'nyi Vykonavchyi Komitet - VUTsVK) stating that he was allowed to live freely in the Ukrainian SSR and that he would suffer no repercussions as a result of his past political activity. The second document was signed by Vlas Chubar, the head of the Soviet Ukrainian government, and Vsevolod Balytsky, the head of the GPU of the Ukrainian SSR. They confirmed in writing that the academic was not subject to searches, arrest or persecution. ${ }^{2}$

Neither of these promises was fulfilled. Hrushevsky would not become president of the All-Ukrainian Academy of Sciences; in 1931 he was secretly forbidden to live in Ukraine; in June 1927 he was subjected to a sudden and total search; and in March 1931 he was arrested. He would be persecuted until his very death in Kislovodsk in November 1934.

To a significant degree all these acts of the regime are manifested in the contents of the absolutely top-secret dossier that was opened on the scholar. This dossier comprises nine volumes and contains over 4,000 different documents and materials. The documents include statements by secret GPU informers, special reports, informer and operative notes (or extracts), circulars, official Chekist correspondence concerning Mykhailo Hrushevsky, written declarations about his activity (in actual fact, denunciations against him) that were transmitted to the organs of the GPU, results of secret inspections of correspondence written by and to the scholar, as well as letters of individuals who wrote about him or simply mentioned his name.

1. Derzhavnyi Arkhiv Sluzhby Bezpeky Ukrainy, Kyiv (hereafter DA SBU), dossier on M. Hrushevsky \# 7537, vol. 1 , fol. 69 .

2. For more information see: Volodymyr Prystaiko and Iurii Shapoval, Mykhailo Hrushevsky $i$ GPU-NKVD. Trahichne desiatylittia: 1924-1934 (Kyiv, 1996): 19-34. 
An analysis of all this material attests to the fact that for Hrushevsky, life in Ukraine from 1924, and in Russia from 1931, was like living in a "glass house.” Virtually every step in his civic, scholarly, and personal life was scrutinized and thoroughly studied. After this the Chekists established their own line of conduct and recommendations to the party-state structures for their actions vis-a-vis the academician.

\section{Secret informers}

The primary material of the dossier consists of reports of secret informers who were in the academician's milieu. It is true that initially the Chekists did not succeed in creating a wide network of informers; such a network was established only during 1925-1926. At first, probably owing to Hrushevsky's declaration of loyalty to the authorities, they considered the group of scholars headed by Academician Serhii Iefremov, which was dominant in the All-Ukrainian Academy of Sciences, to be more dangerous. Thus, in March 1924 the head of the Counter-Intelligence Department of the Ukrainian GPU, V. Ivanov, wrote: "It is necessary to create a net of our agents not around Hrushevsky but around Iefremov."3

Shortly after, however, another viewpoint came to the fore, according to which Hrushevsky had returned to Ukraine in order to conduct a struggle against the Bolshevik regime from the inside. Immediately after his arrival, the academician met with his colleagues from the UPSR and in conversations with them gave his critical assessment of what he had seen - his views on the general situation in Ukraine. These conversations were immediately noted down by informers, each of whom incidentally had been given nicknames, as had Hrushevsky: "Evropeets" (European), “Akademik," "Belyi” (White), "Udachnyi” (Lucky), "Kulturnik" (Cultural Activist), "Kochubei," "Evgeniia," "Turbogenerator," "Om" (Ohm), "Svidomyi" (Conscious), "Frant" (Dandy), "Ian," and so forth. Some of these secret informers, as, for example, "Kievskii" (probably a scholar from VUAN), were used to help the Chekists gain a thorough grasp of the scholar's role and place in the political history of Ukraine in the twentieth century. In this instance, some of the reports were similar to historical information.

One of the most important informers went by the name of "Diplomat." He was not only close to the academician in VUAN, but was also an old friend of his from the UPSR. Another noted informant was Professor Kostiantyn Shtepa of the Nizhyn Pedagogical Institute, who was recruited in 1928. He moved to Kyiv in 1930 and was used as an agent of the Secret-Political Department of the GPU division of Kyiv oblast'; his pseudonym was "Medvedev." He played a deadly role in the fate of Hrushevsky's daughter Kateryna by providing false information that served as the formal basis for her arrest and sentencing. ${ }^{4}$

3. DA SBU, dossier on M. Hrushevsky \# 7537, vol. 4, fol. 9 .

4. See: O. Iurkova, Diialnist Naukovo-doslidnoi kafedry istorii Ukrainy M. S. Hrushevskoho. 1924-1930 (Kyiv, 1999): 262. 
In 1934 an agent named "Khymera" (Chimera) was called in to monitor Hrushevsky. Earlier he had lived in exile where he was used in the monitoring of Ukrainians living abroad. This individual was extremely close to the academician. In Moscow an "accidental" encounter with Hrushevsky was arranged for him. Afterwards, he visited the scholar's family and then renewed his past connections that were absolutely crucial to the Chekists.

As a rule, reports of secret informers were written in Russian. Occasionally they took the form of direct speech; usually they were already written down by the secret informer. At the same time the Chekists wanted to maintain the cover of their informers. For example, on April 11, 1928, Valerii Horozhanyn, the head of the Secret Department of the Ukrainian GPU, and Borys Kozelsky, the head of the 2nd Department in this same division, sent the following letter to the head of the GPU department of Kyiv okrug: "At the same time we bring to your attention an extract from our agent's report. Under no circumstances should these reports be acted on. Addendum: what has been mentioned."5

First of all, informers noted the academician's positive and negative qualities and his relations with other scholars. Thus, in the notification of the secret informer named "Belyi' of September 1, 1925, we read:

"Academician Hrushevsky is a distinguished figure in all respects. An organizer of great magnitude. Loyal to his word once it is given, even if circumstances prevent him from carrying it out. Occasionally knows how to forget about his personal relations and converses with an enemy as with a friend. A great intriguer. A flatterer. Likes to join intrigues from the rear, through the back door. A person of far ranging enterprise. In the political respect, cannot forget his past." 6

In April 1924, the secret informer, "Kievskii," reported:

"Hrushevsky's most important and mightiest tool that he always sets into motion for the most varied and most unnoticeable motives is Ukraine's past, a past that is brilliant, marvelous, and full of prospects. The structure of Hrushevsky's mind, his line of work, his conduct with his colleagues can only be compared with the politics of a highly educated Jesuit. Hrushevsky should be given full credit for his ability to influence people and place them in a moral or - most importantly - material dependence on him. His principle is never to dismiss without satisfaction a person who has turned to him for help, support, or advice. Naturally, if the person who has turned to him is Ukrainian."'

At the same time "Kievskii" emphasized the danger of the scholarly and organizational activity of the academician, who was editing the journal Ukraina. For the informer, this journal was the center and symbol of Hrushevsky's antiSoviet activity. ${ }^{8}$ Finally, "Kievskii" indicated one more important circumstance

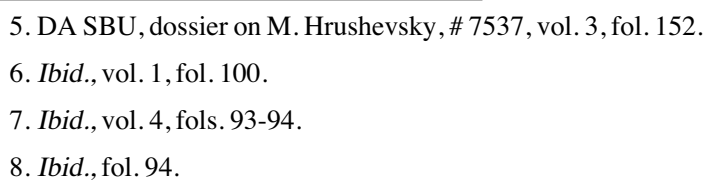


that the Chekists received with particular attention, namely, that in various regions of Ukraine Hrushevsky was creating academic structures, the goal of which was the study of local history and folklore. In "Kievskii's" view, the real goal lies in the fact that local colleagues "will be informants, they will be those "luminaries" who should hold high the idea of an academy with all its concomitant consequences."

Indeed, upon heading the Historical Section of the All-Ukrainian Academy of Sciences after his return, Hrushevsky initiated prodigious scholarly and organizational activity with respect to the study of Ukraine's past. He had plans to create a Historical Institute of Ukraine and an Institute of Primitive Culture. The Chekists regarded these plans, as well as the study of Ukraine that he was organizing by districts, as the academician's attempt to create a center of gravity capable of opposing the regime. The current party-state structures were immediately informed about this. Now it is clear why they began to re-examine their plans for Hrushevsky's role within VUAN.

Even before Mykhailo Hrushevsky's return to Ukraine, it was already understood that he was doomed to the futile prospect of opposition to the group headed by academicians Serhii Iefremov and Ahatanhel Krymsky. These scholars could not pardon his compromise with the Bolsheviks and had great doubts concerning the "purity" of Hrushevksy's ideology. That is why on the eve of his return the Iefremov-Krymsky group manifested its negative attitude toward him. In their reports the secret informers paid special attention to this.

While the academician lived in Kyiv (until his departure for Moscow in 1931) on Pankivska street, no. 9, direct surveillance was carried out by Kyiv Chekists who constantly informed the Kharkiv authorities about his activities. However, they did not merely inform on him. Already on March 15, 1924, they framed a question about how to exploit Hrushevsky. In their opinion, two possibilities existed for such exploitation:

"1. Appoint him president of the All-Ukrainian Academy of Sciences on condition that he carry out the party line;

2. Exploit him along the "Chekist line," i.e., through "the creation around him of a network of our people who, by shielding themselves with his name, will be carrying out our tasks.""10

On March 24, 1924, the head of the Secret-Operative Section and the head of the Counter-Intelligence Department of the Ukrainian GPU criticized the Kyiv Chekists, stressing that "Hrushevsky in the president's chair of the Academy of Sciences does not represent any political expediency for us." Instead, the main task lies in the "exacerbation of differences among the leaders of the Ukrainian chauvinist community." 11

9. Ibid.

10. Cited in V. Prystaiko and Iu. Shapoval, op. cit.: 131.

11. Ibid.: 134 . 
For this very reason the most important task of the secret service was not simply information gathering, but also work that was aimed at deepening the split within the Ukrainian scholarly intelligentsia. This work turned out to be rather successful. Another interesting fact emerged during a conversation between Hrushevsky and one of the secret informers. Already in November 1926, the academician was skeptical about his chances of being elected president of VUAN:

"With regard to his presidency of the Academy, academician M. S. Hrushevsky
stated in a conversation with "Ian" that he is expecting failure, since a hostile
line is being conducted against him. Hrushevsky said that even under pressure
(and in case of necessity, there is no such doubt) he can nevertheless still be
elected president."12

This is indeed what happened. Elections of the presidium and the president of VUAN were held on May 3, 1928. The academy was chaired by Danylo Zabolotny, who was replacing Volodymyr Lypsky. Here is how one of the secret informers described Hrushevsky's behavior: "Hrushevsky completely distanced himself from active participation in the elections. Like Korchak says, he was sitting like an old man with his head bent down, without saying a single word, without raising his hand a single time." 13

\section{Chekist directives and analysis}

A considerable number of circulars, official Chekist correspondence, special analytical reports, and generalized analytical documents about Mykhailo Hrushevsky have been preserved in the dossier. This is an extraordinarily interesting and important part of the dossier, since it contains much valuable information about the internal relations of the Chekists and their work methods.

Thus, for example, before Hrushevsky's arrival, the Chekists were not seriously preoccupied with the Ukrainian Socialist Revolutionaries, as they themselves admitted in one of their letters to the head of the Secret-Operative Section of the GPU V. Ivanov. The reason for this was that "they regarded them as feeble groupings that are degenerating [...]."14 However, shortly afterwards the situation radically changed, and the former members of the UPSR, particularly those close to Hrushevsky, were transformed into permanent "clients" of the GPU. The Kyiv Chekists soon informed the authorities that "we are utilizing a number of measures to seek out loopholes and recruit informers among Hrushevsky's supporters."15

12. DA SBU, dossier on M. Hrushevsky, \# 7537, vol. 4, fol. 277.

13. Ibid., vol. 3, fol. 170 .

14. Ibid., vol. 4, fol. 11.

15. Ibid., fol. 13. 
Very often the work of the Kyiv department of the GPU elicited dissatisfaction on the part of the Kharkiv authorities. Particularly striking in this respect was the situation concerning the preparations for Hrushevsky's jubilee in September 1926. It had been decided to mark the academician's 60th birthday and the 40th anniversary of his scholarly activity at the same time. From the very beginning the Chekists realized that these celebrations would help bolster the academician's authority. They could also be turned into a kind of manifestation, a reminder of the fact that Mykhailo Hrushevsky had entered the history of Ukraine not merely as a researcher but a politician and leader of forces opposing the Bolsheviks.

It so happened that the GPU chiefs in Kharkiv learned of the jubilee celebrations that were being planned in Kyiv from the newspaper Komunist, rather than from their own Kyiv colleagues. Naturally, this caused great displeasure. On September 10, 1926, Karl Karlson, the assistant head of the Ukrainian GPU, sent a document entitled "Directives concerning academician Hrushevsky" to Kyiv, in which he expressed his dissatisfaction. He proposed that administrative punishment be meted out to F. Hrazhul (Dorin), the individual in charge of the Secret-Political Department of the Kyiv GPU.

On September 13, the Kyiv Chekists sent a reply in which they attempted to justify themselves by saying that, owing to the holidays and the fact that the lecturers and associates of VUAN were on vacation, it was impossible to collect the appropriate information. ${ }^{16}$ However, Karlson's position was irreversible. On September 21 , he sent a reply insisting on punishment. He emphasized that "the timely reaction of the departmental apparatus to all events in counter-revolutionary circles, the correct exploitation of your quite good secret informers, will prevent in the future such measures on our part." 17

The documents in the dossier attest to the great difficulties that Hrushevsky's jubilee caused the Chekists, as well as the party and state organs, who ultimately failed (despite appropriate efforts) to "tame" the academician and force him to express himself clearly and favorably about the ruling regime. This was reflected in full measure in the special analytical reports that were written on the basis of statements made by secret informers (It is interesting to note that when there were differing opinions, the Chekists took special note of who said what about Hrushevsky).

In one of their special reports the Kyiv Chekists reached the following conclusion:

"[...] On the whole the jubilee took place in a lackluster fashion, it did not celebrate the relations with Hrushevsky, to a considerable degree this was caused by vacillations concerning our attitude toward the jubilee and the story concerning the autobiography. [This is a reference to a biography that the academician himself was preparing for print. Owing to excessive caution, for a long period of time the authorities did not dare sanction its publication]. Today it will probably

16. Ibid., fols. 100-101.

17. Ibid., fol. 106 
be necessary to seek a pretext in order to elicit Hrushevsky's frankness once again." 18

In a special report of October 7, 1926, the Kyiv Chekists made a more thorough analysis of the course of the solemn tribute to Mykhailo Hrushevsky, which took place on October 3, in the Kyiv Institute of National Education. Here is an extract from this document:

"In the opinion of "Diplomat" and the circle of people whom he is monitoring, the positive results of the jubilee are that:

1. The jubilee is a commendable example of true Soviet democracy.

2.We made a wonderful impression on the foreign guests. The Galicians are in raptures over the jubilee and say that such festivities are possible only in our country.

3. The jubilee exacerbated the struggle among the academic groupings and mainly,

4. The jubilee laid the groundwork for Hrushevsky's election as president of VUAN.

The drawbacks of the jubilee were, first of all, the fact that in his speech Panas Liubchenko [the head of the Executive Committee of Kyiv okrug] spoke too sharply. But in the opinion of "Diplomat," this is typical of Liubchenko. Secondly, it was rather awkward to note that more greetings were received from abroad than from the Soviet okrug-s, and, finally, there were too many different types of people at the reception [...]

In "Diplomat's" opinion, the Soviet authorities' hopes for the jubilee were far from being satisfied 100 percent, for Hrushevsky did not say everything that was demanded of him, and he will not say this even now. It is true that Hrushevsky bribed the jubilee, nevertheless he has still not adequately distanced himself from right-wing Ukrainian elements. However, the secret informer believes that Hrushevsky probably did not express himself consciously today, for he probably does not wish to critically alienate these circles from himself before he occupies the chair of president of the Academy. Hrushevsky is a great tactician and takes everything into account." 19

All the material about the jubilee that was collected by the secret informers and generalized in a preliminary fashion by the Kyiv Chekists formed the basis of a document entitled “A special report about Hrushevsky's jubilee.” It was prepared by the Ukrainian GPU no later than October 10, 1926, and sent to the party-state organs. The authors of this document avoided reaching any explicit conclusions but stated that the jubilee did not touch the periphery.

A series of documents entitled "About academician Hrushevsky," which have been preserved in the dossier, demonstrate that the Chekists considered it imperative to inform the party-state structures about the depressed state of the scholar, his difficult material status, the lack of funds for the publication of scholarly works, and even about the excessively biased attitude toward him on the

18. Ibid., fol. 197.

19. Ibid., fol. 217. 
part of representatives of the nomenklatura (I have already cited the example of Panas Liubchenko who continued to make "attacks" on the academician in the press even after the jubilee). Hrushevsky reacted very painfully to all this.

A unique set of correspondence about the way the Chekists wished to exploit the scholar's situation has also been preserved. The Soviet secret police instructed the secret informer "Evropeets" to confer with Hrushevsky about his more active civic work, e.g., his membership in the Kyiv city council. This is what is stated in one of these special reports:

"Taking advantage of the first convenient moment, "Evropeets" spoke with Hrushevsky, however the results turned out to be unsatisfactory. At first Hrushevsky joked around, but later, when "Evropeets" continued to question him more insistently, Hrushevsky suddenly interrupted him and refused to continue the conversation." 20

Hrushevsky's unwillingness to cooperate with the regime in any form whatsoever made him a "two-faced person" in the Chekists" eyes, especially since the academician had remained in contact with his former colleagues in the UPSR. Although Ivan Lyzanivsky's or Teofan Cherkasky's relations with Hrushevsky were neither simple nor unequivocal, these individuals figure in a number of documents as people who wanted to influence the academician's conduct, particularly after the constant scandals with the representatives of the IefremovKrymsky groups made normal work in VUAN an impossibility. Under these conditions, the Chekists obtained information about the fact that Hrushevsky's supporters were advising him to leave the academy. The following was noted in a special report dated December 29, 1927:

"In our opinion - this is also the opinion of comrade Korniushyn who is leaving today for Kharkiv and will be broaching this question to the Central Committee - it is essential to apply measures so that "Staryk" will not be released from the academy [...]. The question of measures that are crucial for Hrushevsky joining us will emerge in connection with this." 21

However, the GPU provided recommendations not only in connection with the question of engaging Hrushevsky to cooperate with the regime. It is extraordinarily fascinating to learn how the Chekists decided the fate of his scholarly mission abroad in 1928 to attend the International Etruscan Congress in Italy and the International Congress of Historians in Norway. The scholar submitted an application for the trip to the Historical-Philological Department of the AllUkrainian Academy of Sciences, but it was not the academic directors who made the decision whether the academician would be allowed to travel or not. The dossier

20. Ibid., fol. 392 .

21. Ibid., fol. 460 
contains a unique handwritten "Conclusion" made by the head of the Secret Department of the GPU on this question:

"The most recent information available to us attests to the fact that academician M. S. Hrushevsky stubbornly desires to go abroad. We have at our disposal a copy of a letter from Hrushevsky's wife, in which she writes to him, recalling their arrival in the Ukrainian SSR: "So much has happened during this time that it is hard to believe that it has only been four years: it would be enough for eight or more. Therefore, it is completely essential that you have a change of scene." At the present time Hrushevsky's wife and daughter are abroad (near Vienna). There are grounds to believe that after Hrushevsky's recent failures in the Academy (his failure to be elected) he is considering leaving the USSR permanently, which is politically inexpedient for us.

For these reasons the Secret Division of the GPU of the Ukrainian SSR considers it essential that Hrushevsky be denied permission to leave." 22

This document is dated June 7, 1928. On June 15, the Kyiv GPU received the following permission from the Foreign Division of the OGPU in Moscow: "Citizen Hrushevsky, M. S. (Academy of Sciences of the Ukrainian SSR) is permitted to travel to the city of Oslo for participation in the 6th Congress of Historical Sciences. Issue a passport at once upon presentation of the appropriate documents for the mission." 23 However, the Ukrainian power structures still achieved their goal: Hrushevsky received a telegram from the representative body of the Ukrainian SSR in Moscow only on August 13, 1928; meanwhile, the congress in Oslo was opening on August14. "Even if I went," Hrushevsky wrote to Kyrylo Studynsky, "I would not arrive in time [...]."24

In a special report we find information about the source of rumors concerning Hrushevsky's intention to go abroad: "Rumors are emanating from Krymsky's circles that Hrushevsky is preparing to leave the Ukrainian SSR."25

Rumors from circles hostile to the academician also spurred the Chekists to seek a "compromising incident" in Hrushevsky's past. Here is one example. In November 1928 the secret informant named "Frant" provided the information that after returning from Leningrad, academician Volodymyr Peretts, who was one of Hrushevsky's antagonists, recounted a conversation that he had had with S. Oldenburg, the permanent secretary of the All-Union Academy of Sciences. The latter told him that they wanted to elect Hrushevsky academician as early as 1906, but the head of the Academy at the time, the great prince Kostiantyn Kostiantynovych, blocked this process because of Hrushevsky's "separatism." In 1914, when the scholar was arrested and deported to Kazan, academician Shakhmatov appealed to Kostiantyn Kostiantynovych to intercede on behalf of Hrushevsky in view of his scholarly achievements. At the time the great prince

22. Ibid., fol. 480 .

23. Ibid., vol. 3, fol. 244.

24. Ibid., fol. 307.

25. Ibid., vol. 4 , fol. 466 . 
allegedly said that the Academy is making fruitless efforts on his behalf, because he has a letter from Hrushevsky himself. And this letter that was apparently in Oldenburg's possession confirms the loyalty of the academician, who had written that he is for "one indivisible Russia," that he was never a separatist, was always devoted to the throne, etc. On the statement concerning this matter an unknown person had written the following decision: "It is necessary to write to Leningrad with the advisory that a photograph or to a lesser extent a copy of this letter would be extremely valuable to us. $12.11 .{ }^{\prime 26}$

On November 28, 1928, the letter with the question were sent from the GPU of the Ukrainian SSR to the head of the Secret Department of the Permanent Plenipotentiary of the OGPU of the Leningrad military okrug. On November 29, the Kyiv Chekists sent a question that was similar to Kharkiv's and Leningrad's. ${ }^{27}$ However, these quests proved fruitless.

By the end of 1927, it was officially known that Hrushevsky would not be president of VUAN. However, he was permitted to take part in other elections. On January 12,1929, by the authorities' permission and recommendation, he was elected academician of the All-Union Academy of Sciences. At this time an attack had already been launched against Hrushevsky's historical school and that same month the Politbiuro of the Central Committee of the All-Union Communist Party approved a decision about the change of line "concerning material support for Hrushevsky." ${ }^{28}$ A wave of destructive criticism of his views was unleashed in the press. The participants of the 1st All-Union Conference of Marxist Historians, held in Moscow in December 1928-early January 1929, also joined in the attacks.

However, we find somewhat different ideas and assessments in the special reports of the Kyiv GPU. Occasionally, they did not coincide with official and widely circulated assessments. Particularly characteristic are the pronouncements of the secret informer "Evropeets," who believed that

"Soviet rule has adopted an incorrect line towards Hrushevsky, which is leading to increasingly greater divergence between Hrushevsky and Soviet rule [...]. 'Evropeets' confirms that some kind of distrust is constantly felt toward Hrushevsky, for which there are no grounds in the opinion of the secret informer, since Hrushevsky has defined himself; in the event of a war he has nowhere to go, and he would go to work with the Soviet authorities if appropriate measures were adopted for this [...]. Hrushevsky has abandoned his old platform, although he has not quite come around to the Communist platform, but is standing in between these two platforms. Thus, the opinion of "Evropeets" boils down to the fact that Hrushevsky can work with the Soviet authorities, but for this it is necessary that the authorities meet Hrushevsky half way."29

26. Ibid., fol. 493

27. Ibid., fols. 494-495

28. Cited in V. Prystaiko and Iu. Shapoval, op. cit.: 78.

29. DA SBU, dossier on M. Hrushevsky \# 7537, vol. 4, fols. 496-497. 
This is quite an essential point, inasmuch as the cited analytical report was addressed to the party-state leadership, which had already formulated its own opinion of Mykhailo Hrushevsky. During 1929-1930 the pogrom of scholarly establishments headed by the academician or those that had been created through his participation or assistance continued. His dossier contains quite a number of documents that reflect this process and characterize the situation of the academician, who had essentially been cornered..$^{30}$

Particularly demoralizing were the arrests made in connection with the "Union for the Liberation of Ukraine" (Spilka vyzvolennia Ukrainy - SVU). The academician Serhii Iefremov was proclaimed its leader, and he was arrested in July 1929. The Chekists diligently monitored and noted down facts when Hrushevsky attempted to rise to the defense of his former, now neutralized, enemy, and protested against the hounding of Iefremov that had been organized on the highest level. He even planned to make a public appearance in this connection, but in the end did not do this.

The statements of Iefremov, now under arrest, were also gathered and analyzed. An informer who shared a cell with him noted down his reaction. On November 16, 1929, after returning from interrogation, Iefremov mentioned Hrushevsky:

"Even though he is a great figure in society, he also has a petty character, he is an intriguer, he always leans to the side of the strong (he joined the Party of Socialist Revolutionaries in the summer of 1917 because it was the leading one), envious, ambitious, and especially a lover of money and greedy for gain [...]. The struggle was expedient to those who thought to challenge me and other undesirable elements in the Academy. It [the struggle], being masterfully inflated and elaborated (sic), also led conclusively to this grandiose and senseless affair and to the destruction of the Academy. I told Hrushevsky when this affair was cooked up that not only will I suffer but also the Academy and he himself, since in the final reckoning they will also seize him. He was shaken up by what had happened and helplessly excused himself that he had not expected that this could happen." 31

Documents dating to 1930-1931 reflect the Chekists' desire to learn every detail of Hrushevsky's future plans and intentions, all the more so since the first arrests in connection with the "Ukrainian National Center" (Ukrainskyi Natsional'nyi Tsentr - UNTs) were taking place at this time. One of the key names in the protocols of interrogations of the arrested individuals was that of the academician. ${ }^{32}$

On September 5, 1930, when Hrushevsky was vacationing in Kislovodsk, a notification arrived from the official in charge of Ukrnauka (Ukrainian Department of Scholarly Development) in Kyiv about the liquidation, as of September 15, of the Scientific-Research Chair of History of Ukraine. In the 1930s practically all its

30. Ibid., fols. 501-502.

31. Ibid., vol. 5 , fol. 314

32. For more detailed information, see Volodymyr Prystaiko and Iurii Shapoval, Mykhailo Hrushevsky: sprava "UNTs" i ostanni roky (1931-1934) (Kyiv, 1999). 
coworkers would be physically or morally annihilated. ${ }^{33}$ In January 1931, a Historical cycle headed by new directors was created in place of the Historical Section of the All-Ukrainian Academy of Sciences that had been headed by Hrushevsky.

In March 1931, Hrushevsky left for Moscow on a scholarly mission. Surveillance of his movements, particularly after the failed attempt of the Kharkiv Chekists "to make" him into a leader of the UNTs, would continue there. On December 23, 1933, a new (!) dossier would be opened on him as an individual with links to "anti-Soviet elements." 34 These documents were included in vol. 9 of the dossier and for a long period of time were stored in Moscow. On February 10, 1965, this volume, bearing the inscription "To be preserved forever," was transferred from the Central KGB Archive to the 1st Directorate of the Ukrainian KGB as "materials of an archival case of the operative register no. 262 on M. Hrushevsky." 35 The volume contains documents about Hrushevsky's residence in Moscow during 1931-1934, as well as documents from Kislovodsk where the academician died while on vacation in November 1934.

The newly uncovered volume contains documents on the daily surveillance of the scholar. According to these Chekist documents, Hrushevsky became the leader of the "Ukrainian counter-revolution" in Moscow, but for some reason he is "listed" as a member of the "Russian National Party." At this time a new attack on the academician was being launched in Ukraine. However, the "leaders" of Ukraine did not obtain permission for Hrushevsky's dismissal from the academy. Today it is difficult to say why things happened this way, but permission was not granted for this. Neither did the authorities touch the academician in Moscow, although "compromising material" against him was accumulating literally by the hour. In May 1934, the acting head of the Secret-Political Division of the Ukrainian GPU B. Kozelsky sent an announcement to the head of the Secret-Political Directorate of the OGPU of the USSR G. Molchanov concerning a conversation that took place between a secret informer and Viktor Petrovsky, the editor of the military publishing house "Na varti." During this conversation it was revealed that Hrushevsky was intending to flee to Finland by taking advantage of a scholarly mission to Leningrad. ${ }^{36}$ The Moscow authorities took a serious interest in this report and on May 19, 1934, Molchanov requested Kozelsky to send all the documents about the academician's possible flight abroad. ${ }^{37}$ At the same time Molchanov sent the following memorandum to Gorin, the permanent representative of the OGPU of the Leningrad military okrug:

33. For more detailed information, see O. Iurkova, op. cit.: 207-265.

34. V. Prystaiko and Iu. Shapoval, Mykhailo Hrushevsky: sprava "UNTs," op. cit.: 103.

35. DA SBU, case \# 11130, fol. 368

36. Ibid., fol. 240 .

37. Ibid., fol. 243 . 
"According to existing data, academician Hrushevsky Mykhailo Serhiiovych, who is living in Moscow, is preparing to flee abroad in the very near future. In Leningrad a plan for crossing the border illegally has been drawn up. Carry out measures for a detailed investigation of Hrushevsky's connections. In the event of his arrival in Leningrad, take him under external surveillance and monitoring. Hrushevsky is subject to arrest only in the area of the border during an attempt to cross it. During the monitoring process, report with "Special Communication" [VCh: vysoka chastota] no. 9272. Molchanov, 19 May 1934."38

The statements of two secret informers named "Zero" and "Andreev" were sent to Moscow. They recounted their meetings and conversations with Viktor Petrovsky and a former member of the Ukrainian Party of Socialist Revolutionaries Olha Kovalevska. Here is what "Andreev" reported in particular:

"Kovalevska asked me what I had heard about Mykhailo Serhiiovych Hrushevsky. I replied that I had not heard anything in particular and in turn asked what it was about. Kovalevska replied that something is being prepared for Mykhailo Serhiiovych and that he should soon be across the border. Kovalevska avoided giving direct answers to my detailed questioning, declaring that today she will be in a house where she will obtain more detailed information about this." 39

Of course, Viktor Petrovsky and Olha Kovalevska were put under close surveillance, but to no avail. In June the Chekists were interested to know whether Kateryna Hrushevska had gone to Leningrad, but they did not find her there. At that time there was only one Kateryna Hrushevska in all of Leningrad, but her patronymic was not Mykhailivna but Matviivna, and she worked as a statistician for Leningrad Tramway. ${ }^{40}$

In the meantime, the Chekists were maintaining surveillance of those individuals with whom the academician was in contact. However, even during this time they still did not touch Hrushevsky. Moreover, he was offered the possibility to leave on vacation. On September 6, the academician left Moscow and on September 9, 1934, he arrived with his wife and daughter at Mineralni Vody station from where he journeyed to Kislovodsk. From this very moment he was put under surveillance.

Prior to this, on August 17, 1934, the deputy head of the Secret-Political Directorate of the Main Administration of State Security (GUGB) of the NKVD of the USSR, G. Liushkov, sent the following telegram to Lavrushin, the chief of the NKVD in the North Caucasus region:

"Hrushevsky has maintained his leading position among Ukrainian nationalist cadres to this very moment.

38. Ibid., fol. 244

39. Ibid., fol. 248

40. Ibid., fol. 258 . 
We are actively monitoring him according to the "Starets" (Old Man) case that has recovered secret informer data about the preparation for Hrushevsky's flight abroad.

We do not exclude the possibility that Hrushevsky's trip to Kislovodsk will be used for meetings with the organizers of the escape and possibly for its practical realization.

The prevention of Hrushevsky's escape has exceptional political significance.

We propose:

1. To dispatch an experienced operative worker to Kislovodsk for the organization of secret monitoring of Hrushevsky in Kislovodsk;

2. To ensure the secret inspection of his entire correspondence;

3. To ensure constant surveillance of him through intelligence and secret service actions. In the event of his departure, he is to be tailed;

4. To ensure the exposure and verification of Hrushevsky's contacts in Kislovodsk and particularly of those individuals who come to his home to meet with him;

5. Inform us about the progress of Hrushevsky's monitoring by special notification every five days.

We are tailing Hrushevsky." 41

Mykhailo Hrushevsky died on November 24, 1934. His death took place at 2:00 p.m. in O. Rykov Municipal Hospital of Kislovodsk where he had been admitted to Ward no. 2 on November 13, 1934, with a diagnosis of "malignant spinal carbuncle - sepsis." 42 The dossier contains a copy of the academician's complete medical history file no. 1364.43 On November 26, the body of Mykhailo Hrushevsky, accompanied by Maria Sylvestrivna and Kateryna Mykhailivna, was dispatched by train no. 15, which arrived in Kyiv on November 28, at 3:00 p.m., after a two-hour delay. At the train station the deceased was met by the members of a government commission appointed to organize his funeral. The delegation was headed by Vasyl Poraiko, several scholars-academicians, and relatives. The body was brought to the Academy of Sciences where viewing took place from 6:00 to 10:00 p.m. and on the following day, i.e., November 29, from 10:00 a.m. to 1:00 p.m. The funeral took place the next day at Baikove Cemetery.

The NKVD continued to keep an eye on all these sorrowful events and to send informative telegrams to Moscow addressed to V. Balytsky, Ia. Agranov, and K. Pauker. ${ }^{44}$ In my opinion, the fact that this information reached the latter, who was the head of Stalin's personal guard, proves the continued interest of the "leader of nations" in the fate of Mykhailo Hrushevsky, even at this stage of events.

The funeral proceedings were also of interest to the Chekists. One document notes that everything took place calmly and that 600 people accompanied the

41. Ibid., fols. 262-263.

42. Ibid., fol. 310 .

43. For more detailed information, see V. Prystaiko and Iu. Shapoval, Mykhailo Hrushevsky: sprava “UNTs," op. cit.: 107-110.

44. DA SBU, case no. 11130, fols. 313-314. 
scholar on his final journey, of which 400 were present at the cemetery. ${ }^{45}$ In a document signed by B. Kozelsky, the head of the Secret-Political Directorate of the Administration of State Security of the Ukrainian NKVD, we read: "The conveyance of the body from the Academy, the procession to the cemetery, and the funeral took place calmly." 46

Special reports on the reactions to Hrushevsky's death have also been preserved. The Chekists carefully analyzed information about who said what in connection with this sorrowful event. It is interesting to note that immediately after the scholar's death rumors of his violent death began to circulate. This was stated in particular in a special report:

"Anti-Soviet nationalistic circles are attempting to interpret the death of academician Hrushevsky M. S. as an act of violence. In the Institute of Chemical Technology of the All-Ukrainian Academy of Sciences a small group of scholars, discussing the first announcement in the press, indicated that Hrushevsky had in fact been poisoned." 47

\title{
Secretly inspected correspondence
}

It is well known that the secret inspection of correspondence was always one of the most important channels by which the Chekists obtained essential information. The case of Mykhailo Hrushevsky was no exception. Practically his entire correspondence, including personal letters, underwent secret inspection. Quite a few letters, or more accurately, memoranda of letters, were added to special reports.

The dossier contains copies and letters of those individuals who believed that Hrushevsky had betrayed the interests of the struggle for Ukraine's independence after his return from emigration. The Chekists constantly monitored the arrival of such correspondence and analyzed it. A copy of a letter written by readers of the Lviv newspaper Dilo (Action) (this was in fact a letter from the Foreign Committee of the UPSR), which was given to Hrushevsky in Vienna prior to his departure to the Ukrainian SSR, has been preserved. ${ }^{48}$

The copy of this letter bears the following inscription written by the chief of the Counter-Intelligence Division of the Ukrainian GPU Iukhym Kryvets:

"Hrushevsky obtained this letter from the Foreign Committee of the UPSR back in January in Vienna and then gave them a reply. Today this letter is being forwarded to Kyiv not for transmission to Hrushevsky, but definitely for circulation within Ukrainian society with the goal of compromising Hrushevsky."49

\author{
45. Ibid., fol. 322 \\ 46. Ibid. \\ 47. Ibid., fol. 316 . \\ 48. DA SBU, dossier on M. Hrushevsky \# 7537, vol. 4, fol. 18. \\ 49. Ibid.
}


Quite often Hrushevsky would receive letters of this nature, including criticisms. Thus, in January 1927 he was sent a letter by a person masquerading under the pseudonym "Skryvdzhenyi" (Injured). The letter contained an appeal for the academician's help in the defense of former emigrants who had returned to the Ukrainian SSR and been officially amnestied. In fact, they had been registered with the GPU as harmful elements, and the 1926 Ukrainian SSR constitution deprived them of their civil rights. In connection with this letter the head of the Secret Department of the Ukrainian GPU, Valerii Horozhanyn, passed the following resolution: "To Comrade Kozelsky. This letter was delivered to the addressee in vain, it could have been easily held back. Tell this to Kyiv. 15.01."50 Kozelsky had probably already prepared a reply to Kyiv, which he signed together with Horozhanyn. It stated:

"It was not necessary to allow "Skryvdzhenyi's" anonymous document to be forwarded to Hrushevsky's address. Such documents provide Hrushevsky with undesirable arguments against us, even if they are groundless. In the future let the leadership take this under consideration." ${ }^{51}$

Occasionally they did confiscate letters. For example, in February 1931 the Chekists intercepted a letter that never reached the academician. This was an anonymous letter dated February 12. Its author wrote:

"I read with admiration the item in the newspaper of February 11, this year about your protest and that of other respected scholarly workers at the opening session of VUAN against the terror in Western Ukraine. The Academy's action is a good matter, but one thing is confusing: why is the Academy, in rising to the defense of our "western brothers," forgetting about the "eastern" ones? Is it not because our newspapers are writing a lot about the terror in Poland, while remaining silent about the terror in our part of Ukraine? Is it possible that you, respected fathers of scholarship, are unaware of the facts about the terror in our country? Have the tens and hundreds of thousands of people who have been deported and expelled from their native places during the past year alone passed unnoticed by you? Have you not heard how in the dark nights our Ukrainian peasants were chased from their pathetic buildings dressed only in what the "dekulakizers" found them? [...] And the system of taxes on the peasants and the methods of their acquisition - is this not the same kind of terror or simply legalized robbery?

Respected "academicians," peer into our jails, see those who often fill them. And when our investigators interrogate [...] they often interrogate a completely innocent victim for three hours or more a day without a break, bringing people to madness, suicide [...] And is this not terror?"52

50. Cited in V. Prystaiko and Iu. Shapoval, Mykhailo Hrushevsky i GPU-NKVD, op. cit.: 174.

51. DA SBU, dossier on M. Hrushevsky no. 7537, vol. 5, fol. 349.

52. Ibid. A letter to M. Hrushevsky dated February 12, 1931, fols. 1-3. 
Let us turn to another example that clearly illustrates Chekist work practices with letters addressed to Hrushevsky. In February 1929, information (prepared in the Ukrainian language, which clearly exemplifies how the GPU was being "Ukrainianized") was sent from the GPU division of Odessa okrug to the same division in Kyiv. This information, entitled "About citizen Sokolenko with a forwarded document," bears an interesting signature stamp:

"With this the GPU division of Odessa okrug is sending you a recommended document from citizen Sokolenko S. O. addressed to the Ukrainian Academy of Sciences for academician Hrushevsky. Sokolenko, from whom the document originates, appears in our materials as a Ukrainian nationalist who argues in his works in support of the idea of a dictatorship of the peasantry, but according to information that we have at our disposal, he is not quite normal. If you forward this document to the addressee, academician Hrushevsky, there is a request: 1) affix the proper seal at the Kyiv post office; 2) expose the connection between academician Hrushevsky and Sokolenko and his works that are being sent with this document under no. 181. If you consider it unproductive to send the document to Hrushevsky, then we request that you return it to us." ${ }_{53}$

Hrushevsky's business correspondence and his letters to the current party-state or academic leadership were also subjected to secret inspection. For example, he prepared a letter addressed to the Head of the Ukrainian Council of Peoples' Commissars, Vlas Chubar. In it he refuted the latest accusations that he had not recognized Soviet rule. Hrushevsky took umbrage at Chubar's statement that he was paying attention to "a little heap of emigrants" and not working. In his letter he also explained how difficult it was for him to work "under conditions of technical, financial, and censorship obstacles." ${ }^{44}$ This rather lengthy letter was read carefully by someone in the GPU leadership, who added underlinings and question marks. For example, a question mark was added in the margin beside where Hrushevsky wrote:

"My position - I consider that the Soviet government is continuing the work that I was doing with my fellow-thinkers in the Central Rada and that a free Ukrainian literature was carrying out at one time - that it is building socialist Ukrainian statehood, a national worker-peasant culture. In my position I am helping this [...]." 55

Thanks to the secret inspection of his correspondence, the Chekists were able to pursue one of their favorite subjects: Hrushevsky's material interests abroad. This story began when two secret informers of the Kyiv GPU, "Belyi" and "Akademik," reported that in the VUAN offices they accidentally saw an opened letter. It was addressed to the "Academy of Sciences, to the President." A bank in Geneva was

53. Ibid., fol. 193

54. Ibid., vol. 4, fols. 96-99.

55. Ibid., fol. 98. 
informing Hrushevsky about some kinds of changes to his account. This letter was given to the academician, and the Chekists never got their hands on it. However, within a brief period of time they were secretly inspecting a letter to Hrushevsky written in French by a Swiss bank, informing him that in keeping with his request the bank would be responsible for the care of his daughter Kateryna Mykhailivna. ${ }^{56}$ Perhaps this sparked suspicions that Hrushevsky was intending to leave Ukraine at some point and go abroad.

The Chekists also showed an interest in those individuals who expressed support in their letters for the academician. As a rule, these letters were accompanied by instructions to place the letter writers under GPU registration.

The Chekists were also interested in letters that were not directly addressed to Hrushevsky, but contained references to him or his family and milieu. For example, in January 1928 M. Zhukovska sent such a letter to Mykola Chechel in Kharkiv. In connection with this the following instruction was sent from the Secret Department of the Ukrainian GPU to the Kyiv GPU: "Forwarding with this a copy of a letter to Chechel M. F., whom we have on our surveillance register of Ukrainian citizens, we request that a secret inspection of Zhukovska's correspondence be initiated in order to keep track of Chechel's reply." 57

It is interesting to note that in 1924, when Hrushevsky was first taken under surveillance as an untrustworthy individual, a registration card listing him as a member of the UPSR (although he had officially left the party) was created in the Counter-Intelligence Division of the Kyiv GPU department. Point 14 on this card states the following: "Active or not (how is the activity manifested?)." On the signature stamp someone in the GPU wrote the following: "Maintains links by correspondence with foreign countries and in the USSR mainly with [indecipherable] the scholarly world." 58

Of course, all the academician's foreign correspondence was also secretly inspected. For example, in August 1927 he received a letter from Iurii Siryi from Prague. The letter included the text of a speech presented on October 17, 1926, at a meeting of the Kuban communities in the city of Podebrady near Prague. The speech is entitled "Academician M. S. Hrushevsky as an organizer of cultural and scholarly work in Ukraine." The notations on the text of the speech attest to the fact that it was read by the GPU. 59

In November 1928, Hrushevsky received a letter from Volodymyr Vynnychenko, which was, of course, duly noted. In his letter Vynnychenko requested help in locating materials for a novel about the age of Khmelnytsky. His letter, Hrushevsky's reply, and Vynnychenko's thanks for the consultation were all attached to the dossier. ${ }^{60}$

56. Ibid., fols. 417, 420

57. Ibid., vol. 3, fol. 52 .

58. Ibid., vol. 4 , fol. 45

59. Ibid., fols. 428-434.

60. See V. Prystaiko and Iu. Shapoval, Mykhailo Hrushevsky i GPU-NKVD, op. cit.: 221-223. 
Finally, a significant portion of the inspected correspondence consists of letters written by Hrushevsky's adversaries. It was from these very letters that the GPU agents extracted information about those individuals who were preparing to act against the academician and in what manner, and about those individuals that were judging his conduct and their opinions of the scholar. In the first place, this allowed the political police to formulate a strategy of action vis-à-vis the scholar and to deepen the schism within the Ukrainian intelligentsia.

This group of letters clearly reflects the dramatic nature and absurdity of the struggle and resistance into which distinguished Ukrainian scholars were being dragged. These letters attest to the fact that not everyone had sufficient wisdom to judge him as Mykola Vasylenko did in a letter (secretly inspected, of course) written to Mykhailo Slabchenko in May 1927:

"The collection of articles in honor of M. S. Hrushevsky is not his personal affair; in my opinion, this is a phenomenon of a social order. M. S. Hrushevsky is such an eminent and important figure in the development of Ukrainian historical scholarship that he has created an entire epoch. No matter how one considers him as a private individual or social activist, his methods of struggle, etc., no one can repudiate those immense services to scholarship that he has to his credit. When the question of honoring these services is broached, one cannot deny this. Here one must forget about personal relations. They have no significance before the fact that is being honored." 61

In the meantime a large number of letters reflecting the opposite approach to Hrushevsky have been preserved in the dossier. Thus, on September 15, 1926, the Kyiv Chekists sent the following letter to their Kharkiv bosses:

"At the same time we are forwarding a copy of a document, the author of which is citizen Mohyliansky Mykhailo, who at the present time is residing in the city of Chernihiv. In the document he writes to academician Iefremov about his mission to Leningrad; among other things he adds that it will be undesirable for him to be in Kyiv when "the explosion of obligatory and voluntary foul language of the jubilee" will take place. It is obvious that Mohyliansky is talking about Hrushevsky's jubilee."62

Indeed, this is exactly how Mohyliansky expressed himself in his letter. Among other things, he was renowned for the fact that in the first issue of the literary journal Chervonyi shliakh (The Red Path) in 1926, he had published a short story entitled "Vbystvo" (The Murder) about three activists who carry out a political assassination. These men destroy their leader for betraying the national cause. Every person who read this "short story-dream" understood that the author had Hrushevsky in mind when he wrote about the leader-turned-traitor. In his correspondence Mohyliansky expressed himself about the scholar without any euphemisms. He was not the only one to do so.

61. DA SBU, dossier on M. Hrushevsky no. 7537, vol. 4, fol. 461.

62. Ibid., fol. 74. 


\section{Denunciations}

The dossier contains several documents belonging to another favorite genre of the Chekists. These are declarations that were written voluntarily or at the request of agents of the Bolshevik political police by various individuals about the scholarly and organizational activity of Mykhailo Hrushevsky. They were written and transmitted not only to the GPU-NKVD but also to other departments.

For example, one of the first declarations of this kind is dated November 1926. It was written by a graduate student in Hrushevsky's department, not to the GPU but to Ukrholovnauka (the Ukrainian Main Department of Scholarly Development). However, after becoming acquainted with its contents, the current deputy Peoples' Commissar of Education of Ukraine Ia. Riapno sent it "to the attention," as he wrote, of the deputy head of the GPU, Karl Karlson. ${ }^{63}$

Precisely what was "incriminating" to the academician in this letter? First of all, he declared that Hrushevsky does not care about the "proletarization of the department," since he is filling it with "right-wing elements hostile to the proletarian cause."64 Then he criticized Ukrholovnauka for having drawn up a statute according to which graduate students do not enjoy the right to have a decisive voice in the admission of new graduate students, and that this "permits the directors to bring into the department not only people who are hostile to us, but also inept scholars." 65 Naturally, this is followed by concrete examples. First of all, the author of the declaration protests against the acceptance into the graduate program of I. Mandziuk, who is a "a hetmanite according to his views." 66 Then he lists the names of those who, in his opinion, are worthy of being transferred from the status of candidate-graduate student to graduate student. Their status "until this time has not been changed to that of graduate students only because these comrades are ideologically entirely ours." 67 Such graduate students were judged in the declaration as being "neither fish, nor meat." The following conclusion concerning them is reached: "In general, the department cares more about those who are more hostile toward us." 68 Finally, the author of the declaration promised: "I will provide the final supplementary materials later."69

The Chekists reacted to "signals" of this kind particularly actively since at the beginning of his declaration the author emphasized that he is not simply a graduate student but a member of the Communist party. A much more serious "signal" can be found in a declaration to the Ukrainian GPU written in January 1927 by another
63. Ibid., fol. 319 .
64. Ibid., fol. 320 .
65. Ibid.
66. Ibid.
67. Ibid.
68. Ibid., fol. 321
69. Ibid. 
graduate student and party member, this one from Kharkiv. Here very serious accusations are leveled at Hrushevsky:

"I consider it essential to bring the following to the knowledge of the Political Directorate:

As a graduate student of the Kharkiv Scientific-Research Department, I have occasion to meet with workers of the All-Ukrainian Academy of Sciences and be somewhat aware of the work of various sections of the Academy, mainly the Historical Section headed by M. Hrushevsky. The selection of workers and the organization of scholarly work (by regions) elicited my suspicion concerning the existence of a political organization hostile to us, under the screen of the Historical Section [...].

That from the very time of his arrival in Kyiv M. Hrushevsky is surrounding himself with active "fellows" from the Ukrainian counter-revolution (he is very fond of the Socialist Revolutionaries Ivanets, Hlushko, Savchenko, although occasionally he also uses such monarchists with cadet leanings as academician Vasylenko). I am speaking here only of those people whom I personally know as having been "active workers" in the past. If the Political Directorate inspects the others Hrushevsky has organized here, then very likely even more interesting facts will become clear. The fact that this entire group has not changed its convictions and has not become Soviet at all may be judged by Hrushevsky, who to this very time has not declared his relationship with Soviet power, as well as by the tone (the acme of apoliticalness) of the journal Ukraina [...].

This is the "leadership," its center is in Kyiv. Do they have contact with each other?

According to Levchenko, this entire company (besides the named individuals, there are six more people whose names Levchenko did not mention) almost on a regular basis, twice a month, gathers for a "drinking bout" in the Academy building, in the editorial offices of the journal Ukraina. The selection of participants is stable and very punctilious. Most probably this is the group's "plenum" [...]. This is how the center is organized.

The periphery. Hrushevsky has established the study of Ukraine "by regions": the Right-Bank, the Left-Bank, Western Ukraine, Volhynia, Steppe Ukraine, and the Chernihiv region. Hrushevsky "himself" chairs the majority of the regional commissions, and for the most part the leaders are from among "his" people (Western Ukraine - Savchenko; Archeographic - Ivanets; Ancient Kyiv - Shcherbyna, etc.) The main one is probably the commission for Western Ukraine (the office is linked with countries abroad), in which sit two diehards like Fedir Savchenko (Hrushevsky's right-hand man) and Semen Hlushko (his left-hand man, as it would appear).

All these commissions have correspondents in place in their regions. There is information about only two of these correspondents in the Academy: Vasyl H. Kravchenko (Zhytomyr) and V. K. Luhovsky (Chernihiv). They are probably the most respectable, whose inclusion in the list would not be an embarrassment. The remaining correspondents are known only by the commissions that are in contact with them and which issue instructions. What kind of selection this is may be judged by the group of "leaderships."

A close link with foreign countries is maintained through the commission for Western Ukraine. Every month between 200 and 400 dollars are sent to Studynsky's address, for what purpose it is not particularly clear.

This entire group bestirred itself especially during the opposition's action [...]. 
No less characteristic is the selection of graduate students in Hrushevsky's department. This year a certain Mandziuk (an autocephalist and Petliurite whom I know from the Institute) put in his application. Hrushevsky was forcing him through by all possible means. And only the open protest of the Soviet group of graduate students headed by the party member Kaminsky, a promise to lodge a protest against him with Glavnauka [All-Union Main Department of Scholarly Development] temporarily cooled Hrushevsky down, but like before, he is spinning around here and will be unconditionally stuck onto one of the commissions. All the enumerated facts speak unconditionally about the existence under Hrushevsky's wing of an organization that is inimical to us, in the meantime perhaps not particularly active but capable of bringing out a "cabinet of ministers" at the necessary moment [author's emphasis], as the Academy has done in the past.

For this reason it is now necessary to pay particular attention in order to expose this group." 70

After reading this document, one can understand the source of the GPU workers' acute interest in the regional commissions that were created by Hrushevsky, which - under the pen of the excessively diligent graduate student - appeared to be centers of discord on the periphery.

Finally, there is a declaration dated December 27, 1930, several months before Hrushevsky's arrest. At this time arrests were taking place, as well as interrogations of those who had already been accused of membership in an underground organization that was headed by him. It was structured to suit the accusation of "anti-Soviet activity" that the Chekists were constructing against the scholar and his milieu. First of all, the author of the declaration notes that once he and other graduate students managed to enter the department, "in fact we fell into a fascist state that existed within the Soviet state - even our terminology terrified the Hrushevskyites (in connection with which several incidents took place)."71

Emphasizing that the "entire actively hostile element of Soviet Ukraine from all corners of the USSR and the Ukrainian SSR" was being selected for the department, the author of the declaration named those "counter-revolutionaries" who had been handpicked by Hrushevsky. Here is an example of his characterizations:

"The leading center of the department is M. S. Hrushevsky, O. S. Hrushevsky, a great fool and the brother of the great historian, is no less an enemy of the proletariat, Shcherbyna, V. I., some sort of uncle of Hrushevsky, a liberal with cadet leanings, Hermaize, I. Iu., a fascist, Savchenko, Fedir Ia., Hrushevsky's personal secretary, the former head of the national union of the Ukrainian emigration in Prague (the facts have not been confirmed). Incidentally, Savchenko is the former friend and Institute colleague of Ozersky, the former head of Ukrnauka. Through the agency of this Savchenko, who is extremely perspicacious and clever, Hrushevska K. M., the daughter of M. S. Hrushevsky, a true seed of her roots, is attempting to shore up the shaky ground beneath her feet; in her works she has taken upon herself the honorable role of fascism in order "to revise the

70. Ibid., vol. 2, fols. 312-313

71. Ibid., fol. 5 , fol. 524 . 
views of Engels." And finally the most decent person is Klymenko P. V., who was sent from Kharkiv. He is a former Social Democrat; owing to his principled conflict with the entire brotherhood of Hrushevsky's fatherland he has now been dismissed from all paying jobs in Hrushevsky's institutions."

This is followed by a list of names of the scholarly collaborators and graduate students in the department. ${ }^{72}$

It is completely understandable that this kind of description and generally this type of document could be exploited (and was exploited) in the fabrication of accusations against Mykhailo Hrushevsky and his milieu. Indeed, all the individuals named in the denunciations were subjected to repressions in one form or another.

\section{Brief conclusions}

At one time Oleksander Ohloblyn made venomously biting remarks about those who asserted that Hrushevsky had returned to Ukraine on directives from the Ukrainian Party of Socialist Revolutionaries with the aim of conducting "underground work" that was to be crowned by a revolt against the Bolsheviks. In Ohloblyn's opinion, "this historical fantasy can only elicit amazement and smiles from those who were more knowledgeable about Soviet conditions in those days, relations among the emigrés, and, ultimately, his [Hrushevsky's] character [...]. There was nothing unusual in the fact that in the 1930s similar accusations against Hrushevsky were leveled by the NKVD and the Communist party, who needed formal grounds for his liquidation." ${ }^{\prime 3}$ An analysis of the documents contained in Mykhailo Hrushevsky's dossier serves as convincing confirmation of the words of Oleksander Ohloblyn, who, in fact, did not sympathize with the academician in the 1920s and 1930s.

The dossier of Mykhailo Hrushevsky may also serve as a good example for researching the ways in which the GPU-NKVD extracted information and the mechanisms that lay at the heart of this activity. At the same time, this case also demonstrates the crucial need for scholars to utilize not secondary but primary documented sources, most of which, unfortunately, are still inaccessible to researchers of Communist totalitarianism.

(Translated from the Ukrainian by Marta D. Olynyk with the financial support of the Harvard Ukrainian Research Institute)

National Academy of Sciences of Ukraine Institute for Political and Ethnic Studies

Kyiv-11

Kutuzov st. 8

e-mail:shapoval@history.kiev.ua

72. Ibid.

73. Oleksander Ohloblyn, "Mykhailo Hrushevsky na tli doby: dumky pro tretiu i ostanniu dobu istoryka (1924-1934)," Ukrainskyi istoryk , 1-4 (1996): 81. 